\title{
A global map of human pressures on tropical coral reefs
}

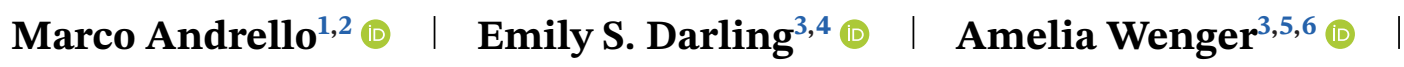 \\ Andrés F. Suárez-Castro $^{6,7}$ | Sharla Gelfand $^{8}$ | Gabby N. Ahmadia ${ }^{9}$
}

${ }^{1}$ Institute for the Study of Anthropic Impacts and Sustainability in the Marine Environment, National Research Council, CNR-IAS, Rome, Italy

${ }^{2}$ MARBEC, Université de Montpellier, Montpellier, France

${ }^{3}$ Wildlife Conservation Society, Marine Program, Bronx, New York, USA

${ }^{4}$ Department of Ecology and Evolutionary Biology, University of Toronto, Toronto, Ontario, Canada

${ }^{5}$ School of Earth and Environmental Sciences, University of Queensland, St. Lucia, Queensland, Australia

${ }^{6}$ Centre for Biodiversity and Conservation Science, University of Queensland, St. Lucia, Queensland, Australia

${ }^{7}$ Instituto de Investigación de Recursos Biológicos Alexander von Humboldt, Distrito Capital, Bogotá, Colombia

${ }^{8}$ Independent consultant, Toronto, Ontario, Canada

${ }^{9}$ Oceans Conservation, World Wildlife Fund, District of Colombia, Washington, USA

\section{Correspondence}

Emily Darling, Marine Program, Wildlife Conservation Society, 2300 Southern Blvd, Bronx NY, USA.

Email: edarling@wcs.org

The authors Marco Andrello and Emily Darling contributed equally to this work as shared first authors.

\begin{abstract}
As human activities on the world's oceans intensify, mapping human pressure is essential to develop appropriate conservation strategies and prioritize investments with limited resources. Here, we map six human (nonclimatic) pressures on coral reefs using the latest quantitative data on fishing, water pollution (nitrogen and sediments), coastal population, industrial development, and tourism. Using a percentile approach to rank different stressors, we identify the topranked local pressure and estimate a cumulative pressure index for 54,596 global coral reef pixels at $0.05^{\circ}(\sim 5 \mathrm{~km})$ resolution. We find that coral reefs are exposed to multiple intense local pressures: fishing and water pollution (nutrients and sediments) are the most common top-ranked pressures worldwide (in $30.8 \%$ and $32.3 \%$ of reef cells, respectively), although each pressure was ranked as a top pressure in some locations. We also find that local pressures are similar inside and outside a proposed global portfolio of coral reef climate refugia, suggesting that even potential climate refugia have high levels of local human pressure that require effective management. Our findings and datasets provide the best available information that can ensure local pressures are effectively managed across the world's coral reefs.
\end{abstract}

\section{KEYWORDS}

climate change, coastal development, fishing, marine conservation, nitrogen, oceans, sedimentation, threat mapping, tourism, water pollution

\section{1 | INTRODUCTION}

Coastal and marine biodiversity globally are threatened by the expanding and intensifying impacts and interactions of human activities and climate change (He \& Silliman, 2019;
O'Hara et al., 2021). Implementing solutions to mitigate pressures on ocean ecosystems is a key strategy to slow and reverse biodiversity decline and maintain ecosystem functioning, integrity, and resilience. Being more intentional in allocating limited conservation resources to manage 
pressures will be critical to achieve the Convention on Biological Diversity's Post-2020 Global Biodiversity Framework. Mapping pressures on ecosystems can identify the most threatening activities to ecological resilience and integrity (Tulloch et al., 2015), predict ecological conditions to prioritize climate adaptation or mitigation responses (Grantham et al., 2020), and prioritize where climate change is most likely to interact with local human impacts (He \& Silliman, 2019). However, failing to address local pressures can also increase the risk of damaging additive or synergistic interactions with climate change, which can ultimately undermine the effectiveness of conservation interventions (He \& Silliman, 2019). Therefore, tailored approaches are urgently needed to guide appropriate conservation strategies at local scales and avoid further ecosystem degradation (Allan et al., 2019; Tulloch et al., 2020).

Coral reefs are among the most diverse marine ecosystems on the planet: a critical source of livelihoods, culture, and food security for millions of people, and declining at alarming rates from global and local pressures (Eddy et al., 2018). As the impacts of climate change accelerate thermal stress, coral bleaching, ocean acidification, and sea level rise (Hoegh-Guldberg et al., 2018), decarbonization is a defining challenge for the survival of functioning coral reefs (Darling et al., 2019; Morrison et al., 2019). Complementary to decarbonization, addressing nonclimatic human pressures remains crucial for maintaining coral reef function and resilience amidst climate change (Shaver et al., 2018), and is a foundation of coral reef conservation initiatives worldwide.

With the exception of some remote "wilderness" areas (McClanahan et al., 2021), fishing, pollution, and development can have damaging population and ecosystemlevel effects on coral reefs (Burke et al., 2011). Identifying and addressing these nonclimatic pressures can enhance resistance and recovery from coral bleaching (Claar et al., 2020; Shaver et al., 2018), reduce coral disease (Lamb et al., 2016), and is particularly important within potential climate refugia that are expected to maintain functioning coral reefs over the coming decades (Beyer et al., 2018; Côté et al., 2016; Darling et al., 2019). One of the first global assessments of human pressures on coral reefs was The Reefs at Risk project (Burke et al., 1998; Burke et al., 2011), which has been a valuable tool guiding coral reef managers for the past 20 years. However, recent advances in satellite imagery and analytical approaches have improved our ability to quantify human pressures on coral reefs. These advances include a global "gravity" index of coral reefspecific fishing pressure based on travel time to markets (Cinner et al., 2016, 2018), more realistic models of land use change and runoff (Borrelli et al., 2017), and updated estimates of human populations (Center for International
Earth Science Information Network - CIESIN - Columbia University, 2018).

Here, we map local pressures on the world's coral reefs with new and improved quantitative data layers. This advances the "low," "medium," and "high" categories of threat in the Reefs and Risk approach and we make the underlying data layers freely available along with an interactive web map, and a series of report cards for locations of potential climate refugia (see Acknowledgments and Data Accessibility Statement). This information can inform conservation plans with more rigorous and comprehensive information by identifying the top-ranked pressure and cumulative pressures at a $\sim 5 \mathrm{~km}$ resolution for coral reef habitat, globally. This can also help reef managers, practitioners, and funders identify appropriate interventions matched to top threats and prioritize management actions based on cumulative pressure, for example, prioritizing threat mitigation to areas under high pressure or maintaining sustainable use within areas of lower pressure. We also evaluated local pressures across a global portfolio of proposed climate refugia for coral reefs (Beyer et al., 2018) to help inform conservation efforts of several multimillion dollar global conservation initiatives, including Bloomberg Philanthropies' Vibrant Oceans Initiative, the Coral Reef Rescue Initiative, and the United Nations' Global Coral Reef Fund. Intended to be combined with local knowledge and expertise, our analyses will support decisionmakers to identify and mitigate the top pressures on coral reefs to support the persistence of coral reefs and their associated wealth of services to humanity amidst a rapidly changing climate.

\section{2 | METHODS}

\section{1 | Data layers}

Tropical coral reef locations were taken from Beyer et al. (2018) based on the Global Distribution of Coral Reefs dataset (UNEP-WCMC, WorldFish Centre, WRI, \& TNC, 2010) and updates from the National Oceanic and Atmospheric Administration (NOAA). We mapped reef locations onto a $0.05^{\circ}$ resolution $(\sim 5 \mathrm{~km})$ raster dataset, resulting in 54,596 reef-containing raster grid cells worldwide.

We integrated spatial data layers on six local pressures on coral reefs: fishing (typically artisanal or small-scale fisheries), sediment and nitrogen pollution, coastal population, industrial development, and tourism (Table 1). We define a "pressure" as a contextual variable that can, under certain conditions or above a specific magnitude, significantly degrade the ecological function, productivity, or resilience of coral reefs. While pressures can result in negative consequences for reefs, they are also crucial activities for livelihoods and wellbeing (e.g., small-scale fisheries 
TA B L E 1 Data layers used to quantify six local pressures on coral reef biodiversity, functioning, and persistence

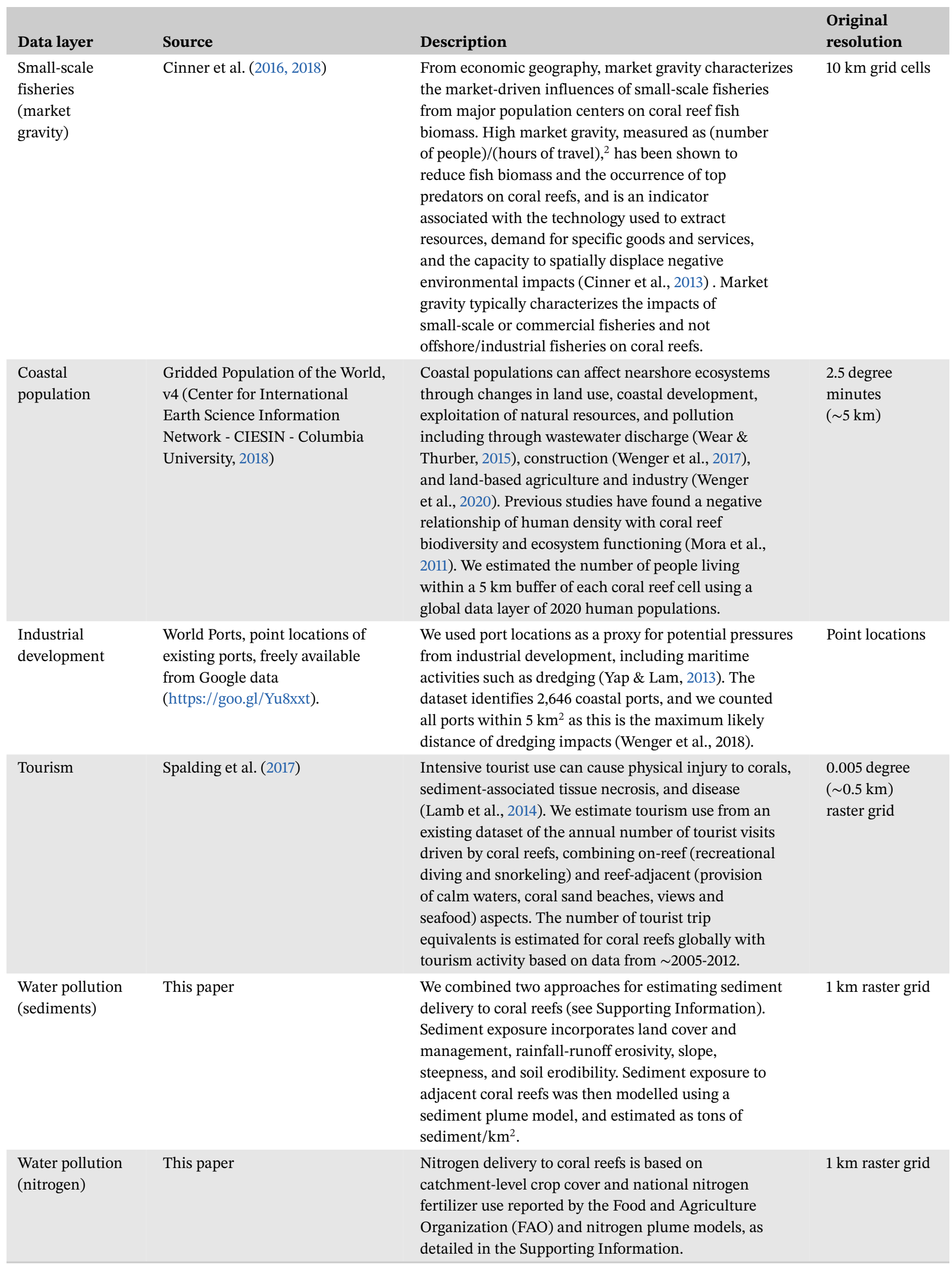


and tourism). The goal of our analysis is to help managers make decisions on which pressures to manage in different locations, with the vision that sustainable management can ensure the long-term persistence of coral reef ecosystems and coastal communities who depend on reef-related ecosystem services. More details about the definition, calculation, and limitations of each pressure can be found in the Supporting Information.

To compare local pressures inside and outside potential climate refugia, we used the Beyer et al. (2018) "50 Reefs" analysis that identified 83 areas as potential coral reef climate refugia based on an analysis of past, present, and future climate, cyclones, and larval connectivity. Each refugium contains approximately $500 \mathrm{~km}^{2}$ of coral reef habitat; overall, the 83 refugia encompass 19,161 coral reef cells (out of 54,596 , or $35.1 \%$ ).

\section{2 | Analysis}

We first converted a raster dataset of coral reef locations into a vector layer of 54,596 square reef polygons $\left(0.05^{\circ}\right.$ $\times 0.05^{\circ}$; approximately $\left.5 \mathrm{~km} \times 5 \mathrm{~km}\right)$ and projected each pressure data layer (Table 1) onto this dataset using a WGS84 coordinate reference system. To rank pressures within each cell, we calculated the percentile of each pressure within a cell from the global distribution of each pressure (see Supporting Information). The top pressure within each cell was identified as the pressure with the highest percentile compared to other pressures. The absolute values associated with various percentiles are shown in Figure S1. While this approach is limited by the assumption that the percentile values of different pressures are directly comparable, it allows for the direct comparison of different pressures and minimizes the impact of extreme values (Figure S1). We then calculated a cumulative pressure impact score for each reef pixel as the average of the percentiles of the six pressure layers.

To evaluate pressures within potential climate refugia, we extracted the median percentile of reef cells within each "50 Reef" location for each pressure; the top-ranked pressure was identified as the pressure with the highest median percentile. However, the spatial variability of pressures is also important for conservation and management planning within potential climate refugia (see Box 1) and there are limitations of a ranking approach that users should be aware of (see Supporting Information).

\section{3 | RESULTS}

\section{1 | Top-ranked and cumulative pressures}

Water pollution and fishing were the most frequently topranked nonclimate pressures, identified as a top pressure in 34,461 reef cells, or $63.1 \%$ of the world's coral reefs (Figure 1). Water pollution was the top-ranked pressure in 17,620 reef cells, or $32.3 \%$ of all reef cells (sediment pollution: $n=9,167$ or $16.8 \%$; nitrogen pollution, $n=8,453$ or 15.5\%; Figures S2-S3) and fishing was the top-ranked pressure in 16,841 out of 54,596 reef cells, or $30.8 \%$ (Figure S4). Coastal population was a top-ranked pressure in 10,741 reef cells (19.7\%), followed by tourism $(n=7,971$, or $14.6 \%)$ and industrial development ( $n=1,423$, or 2.6\%; Figures S5-S7).

All coral reef regions have reefs with high cumulative impact scores (Figure 2). Areas with higher cumulative impact scores are typically located near the coasts of continents and islands, while remote reefs, not surprisingly, have lower cumulative impact scores.

\section{2 | Regional variation}

There was substantial variation within- and betweenregions in individual and cumulative pressures (Figure 3; see Figure S8 for region classifications). The Western Indian Ocean, Southeast Asia, and North Pacific Ocean regions had high, on average, pressures compared to other regions. Within-region variation was also notable. For example, while the Central Indian Ocean region has low regional averages for sediment and nitrogen pollution pressures, some reefs in this region have the highest values (percentiles) of these pressures globally (e.g., high sedimentation from upstream logging activities in Madagascar, Maina et al., 2013; see outliers in Figure 3). Similarly, while Pacific regions (Australia, Micronesia, Polynesia, and Melanesia) have the lowest median fishing pressures by region, individual reef cells within these regions have some of the highest fishing pressure percentiles globally. Regional variability further highlights the need to match conservation and management interventions to the appropriate scale and location of local pressures.

We also observed variation in the relative distribution of top-ranked pressures by region (Figure S9). Fishing was a top-ranked pressure in all regions, but in different proportions relative to other top-ranked pressures, ranging from $19.8 \%$ of reef cells in the Eastern Tropical Pacific to $49.6 \%$ in Australia. Water pollution (sediments and nitrogen) exhibited even larger regional variation, from $1.4 \%$ of reef cells in Micronesia to $47.9 \%$ of reef cells in Melanesia.

Top-ranked pressures were typically associated with high percentiles of the pressure, but there were also cells where top-ranked threats comprised low percentiles, especially for fishing (Figure S10). These cells were typically located in remote areas where other pressures were also low, for example the uninhabited islands and reefs of the Chagos Archipelago, the Federated States of Micronesia, New Caledonia, and Tuvalu, and more remote islands 

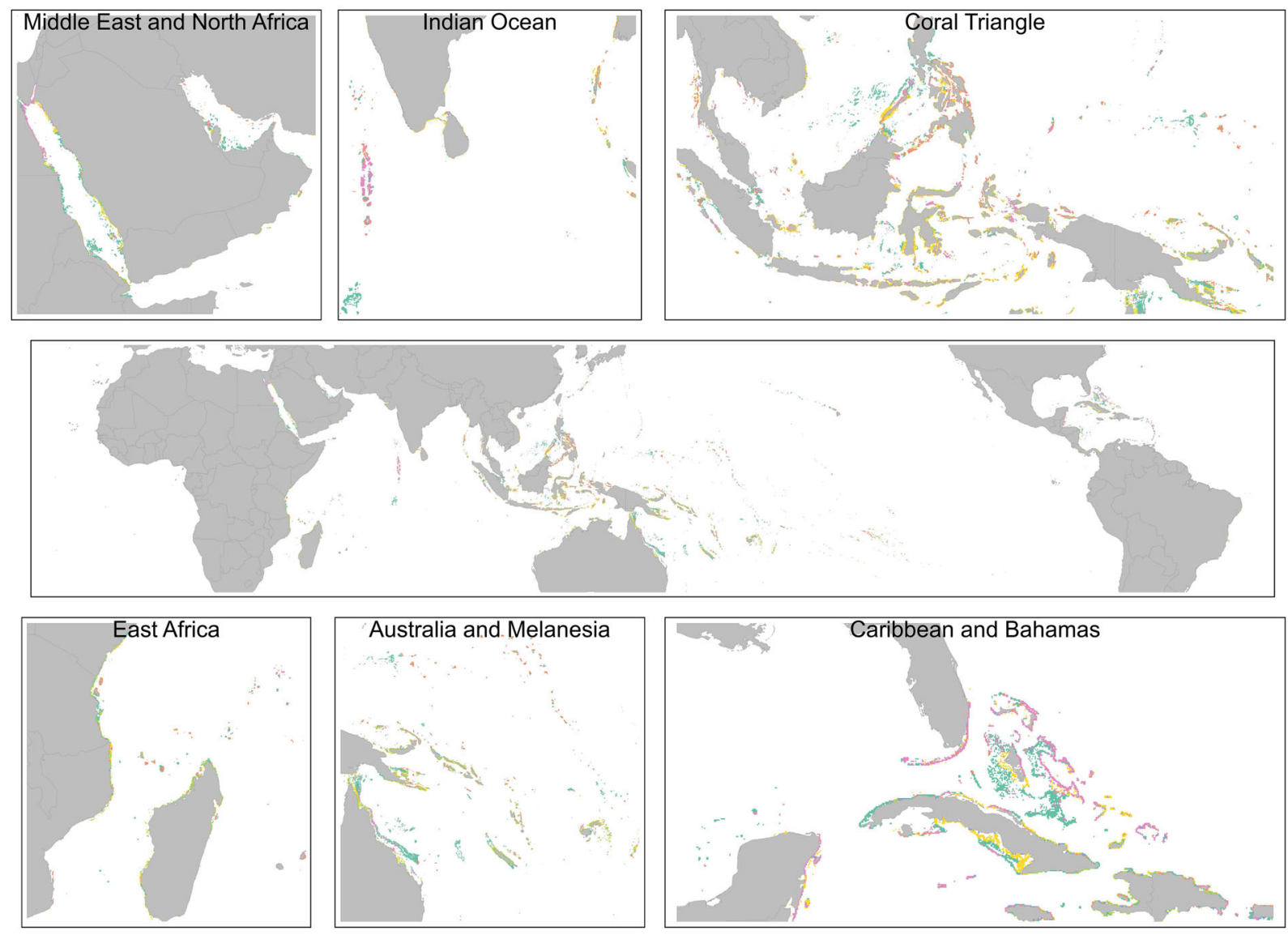

Pressure

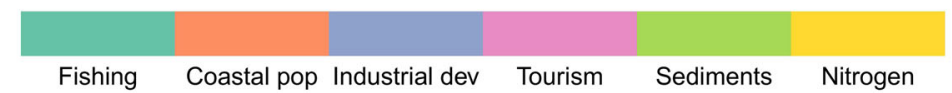

F I G U R E 1 Top-ranked local pressures for coral reefs. The top-ranked pressure in each coral reef cell was identified by comparing each cell's percentiles across different pressure layers. Colors indicate the top ranked pressure. Panels show global (middle) and insets of key coral reef geographies (top and bottom panels)

of Australia's Great Barrier Reef (Figure S4). In contrast, industrial development was ranked as a top pressure only at very high levels of potential impact, for example, a cell with up to eight ports near Puerto La Cruz, Venezuela (Figure S7).

\section{3 | Climate refugia}

The identity and magnitude of local pressures were largely consistent inside and outside a proposed global portfolio of climate refugia (Beyer et al., 2018; Figure 4a). Reef cells inside and outside potential climate refugia were exposed to similar levels of nonclimate pressures, although reef cells inside refugia consistently had more cells with higher impacts of local pressures than nonrefugia cells (see purple areas in Figure 4a). The top-ranked pressures were also similar between refugia and nonrefugia reef cells (Figure 4b).
Water quality was the top-ranked pressure in 30 of the 83 refugia (or $36 \%$; sediment pollution in 11 refugia or 13\%; nitrogen pollution in 19 refugia or $23 \%$ ) and fishing was identified as the top pressure in 27 of the 83 refugia (33\%). Coastal population was a top-ranked pressure in 16 refugia (19\%) and tourism in 10 refugia (12\%); industrial development was not identified a top pressure for any refugium (Figure S11). Refugia in Southeast Asia, Middle East and North Africa, East Africa, and the CaribbeanAtlantic typically have higher cumulative pressure scores, while refugia in Australia, Micronesia, and Polynesia have lower pressures and cumulative impact scores (Figure S12).

\section{4 | DISCUSSION}

Many coral reefs occur adjacent to coastal populations that are connected to transnational and global economies, 

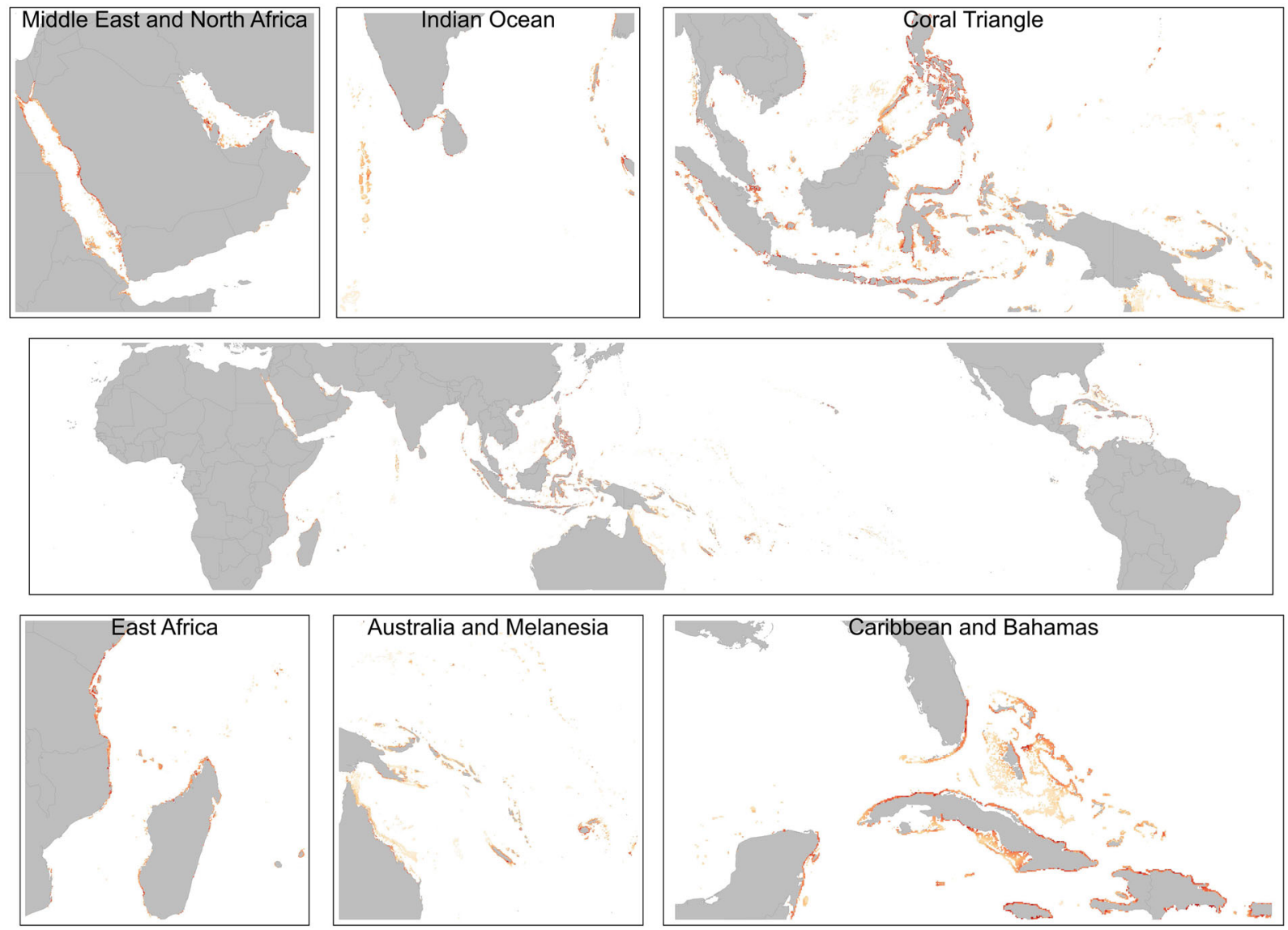

Cumulative impact score

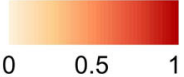

F I G U R E 2 Cumulative impact of local pressures on coral reefs. Cumulative impact scores for each reef cell, estimated by combining pressure scores of each of the different data layers in Figure 1. Panels show global (middle) and insets of key coral reef geographies (top and bottom panels); darker colors indicate higher cumulative pressure scores than lighter colors (lower cumulative scores)

where achieving positive conservation outcomes requires sound science to identify top pressures to inform the codesign of appropriate management interventions at various scales (Tulloch et al., 2015). This is particularly salient in the context of climate change, where sustainably managing local and nonclimate pressures can help buffer resistance or provide essential safeguards for recovery following climate extremes (He \& Silliman, 2019; Lamb et al., 2016). Here, we map local human pressures at a highresolution across 54,596 coral reef pixels globally. Our findings improve past global assessments and provide new insights into the multiple local pressures on coral reefs. For example, in the Reefs at Risk project (Burke et al., 2011), overfishing and coastal development were identified as the two top pressures affecting about half of coral reefs globally. A subsequent survey of managers (Wear, 2016) confirmed the results of the Reefs at Risk analysis but added watershed-based pollution as a top pressure. Here, our findings identify water pollution and fishing as the top- ranked local pressures on coral reefs, affecting 34,461 out of 54,596 reef cells (63.1\% of the world's coral reefs). Additionally, coastal population pressure can also have water pollution impact, for example, from wastewater and stormwater runoff, suggesting water pollution may be an even greater pressure on coral reefs than previously estimated (Burke et. al, 2011). Overall, this suggests an ongoing paradigm shift that identifies the importance of water pollution as a top pressure on coral reefs and highlights the importance of focusing on land-sea approaches for coral reef conservation, such as ridge to reef conservation, integrated watershed management, and wastewater management (Maina et al., 2013; Wenger et al., 2017, 2020). The good news is that a substantial body of conservation science underpins how to design, implement, and measure the success of coral reef management, for example by strengthening local governance (Cinner et al., 2016), intervening in unsustainable market-based demands (Oyanedel et al., 2021), strengthening regulations to keep land use change at sustainable 

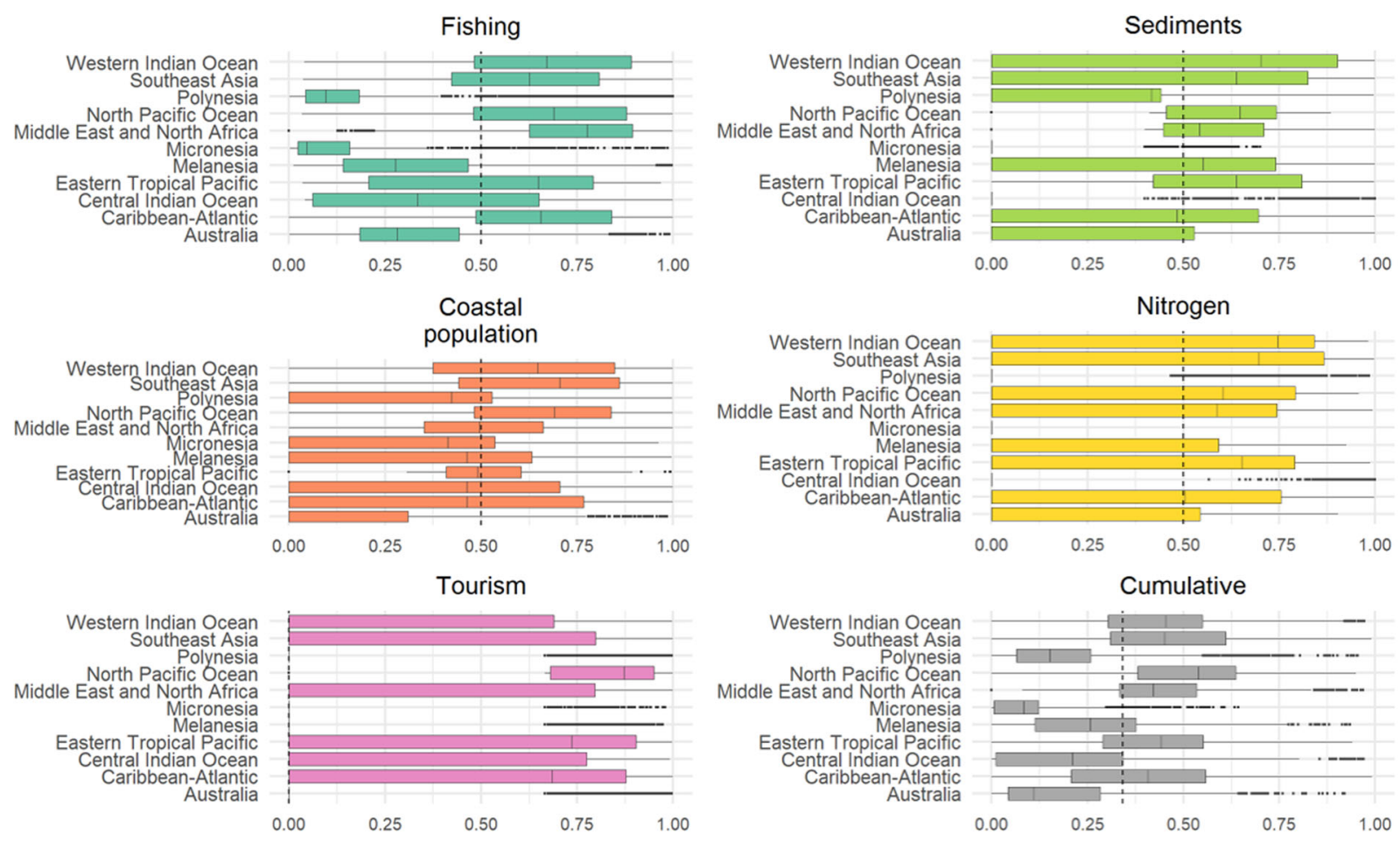

F I G U R E 3 Regional comparisons of individual and cumulative local pressures on coral reefs. Dashed line shows global median, and boxplots show the 25th, 50th (median), and 75th quantile; outliers are points beyond the whiskers (1.5* interquartile range, or the distance between the first and third quartiles). Pressure values ( $x$-axis) are distributed from 0 (lowest value in data layer) to 1 (highest value in data layer). Note that the global median of the tourism pressure is zero because more than half of reef cells have zero tourism and percentiles are tied at zero

levels (Wenger et al., 2020), and improving wastewater management (Wear et al., 2021; Wenger et al., 2017).

While each of the six data layers (Table 1) have been demonstrated to alter coral reefs at some magnitude of impact (Cinner et al., 2016; Darling et al., 2019; Wenger et al., 2020), managing pressures must balance human well-being and ecosystem health, particularly for the millions of people worldwide who rely on coral reefs for livelihoods, culture, food security, and coastal protection. Pressures do not need to be "removed" entirely but managed sustainably within complex social, political, and environmental contexts. For example, fisheries management can maintain yields and productivity that delivers a critical source of nutrition and food security to coastal populations (Hicks et al., 2019; McClanahan et al., 2011). Similarly, well-managed coral reef tourism can maintain an estimated value of US\$36 billion per year (Spalding et al., 2017). However, intensive tourist use can cause physical injury, sediment-associated tissue necrosis, and coral disease (Lamb et al., 2014), and additionally jeopardize the effectiveness of existing management through the growth of tourism infrastructure, such as uncontrolled coastal development, dredging, mangrove loss, or inadequate wastewater treatment (Suchley \& Alvarez-Filip,
2018). Identifying sustainable and unsustainable levels of each pressure and integrating this into management planning is a crucial next step. While we provide highresolution spatial maps of local pressures, we caution that conservation interventions must address the broader social and economic drivers of the pressures that often operate at larger scales, for example multinational investment in fisheries subsidies or global demand for development projects in the "Blue Economy" (Bennett et al., 2019).

These results have immediate application for coral reef conservation efforts. Facing the increasing impacts of climate change and most notably severe mass coral bleaching, several major global efforts are taking a "refugiafirst" approach, prioritizing conservation and management interventions to potential "cool spots" of climate refugia expected to escape the greatest impacts of bleaching and mass mortality of reef-building corals (Beyer et al., 2018; Darling et al., 2019). This is further aligned with theory, whereby coastal ecosystems facing extreme levels of climate stress-like coral reefs-can have the most successful outcomes from local conservation in climate change refugia, although managing local stressors outside of refugia can also help buffer essential recovery following climate disturbances (He \& Silliman, 2019; MacNeil et al., 


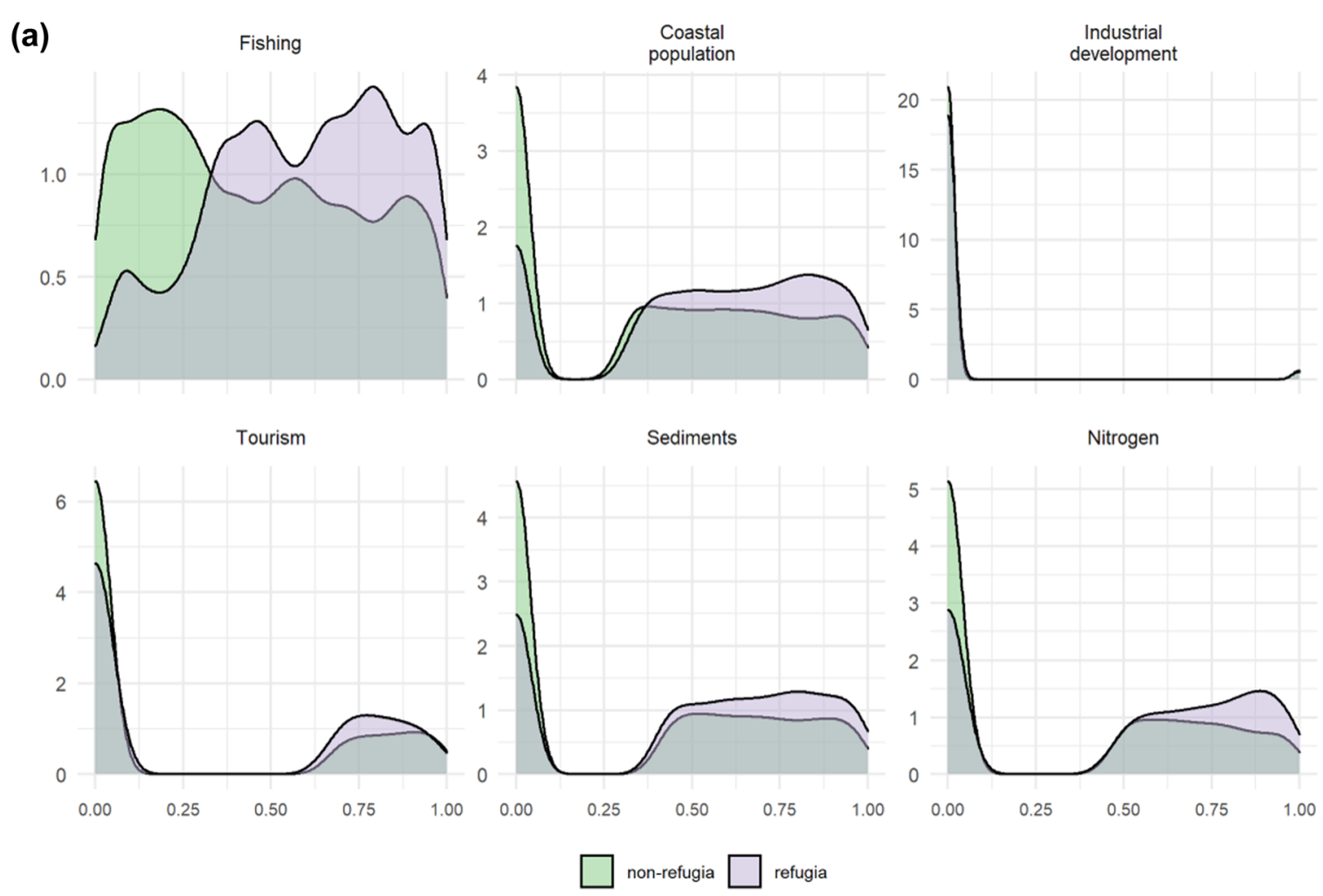

(b)

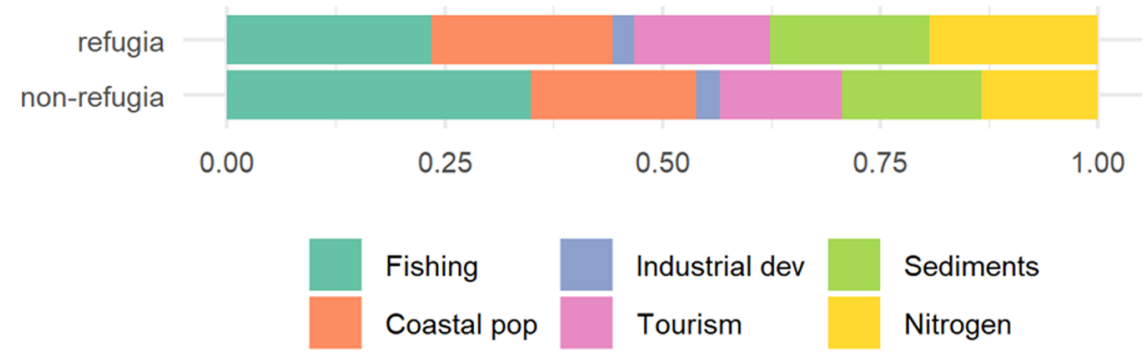

F I G U R E 4 Local pressures across climate refugia. (a) Density distribution of local pressure values inside a global portfolio of potential climate refugia ( $n=19,161$ reef cells) compared to sites expected to have higher climate impacts ( $n=35,435$ reef cells). Pressure values range from 0 (lowest value in global data layer) to 1 (highest value) and the $y$-axis shows the frequency of values. (b) Comparison of top pressures between refugia and nonrefugia. Nonrefugia typically have more fishing pressure and less nitrogen pollution than refugia, but broadly the top-ranked pressures are very similar among refugia and nonrefugia reef cells.

2019). Here, we show that the occurrence of local pressures is similar between refugia and nonrefugia locations, providing an opportunity for efforts to mitigate local pressures to scale up beyond climate refugia and to include nonrefugia locations or disturbed reefs in a broader seascape approach to adaptation and resilience (Darling et al., 2019; Webster et al., 2017). From local to global scales, our results provide information that can be quickly integrated into ongoing coral reef conservation efforts, for example to prioritize threat mitigation efforts for reefs facing high pressures, or to maintain sustainable use through precautionary management for reefs with lower pressures (Campbell et al., 2020).

Our analysis has several important caveats. First, our analysis only ranks and compares pressures that are avail- able as global data layers. In some locations, important pressures will not be included in our analysis and might require urgent conservation action, such as destructive fishing practices (Bailey \& Sumaila, 2015; P. Lestari, personal communication) or biological invasions by crown of thorn starfish (De'ath et al., 2012). This highlights the importance of co-designing conservation interventions with expert knowledge from local resource users, communities, traditional owners, and Indigenous peoples to effectively incorporate global and local information for coral reef conservation (Harris et al., 2017). Second, our analysis assumes that relative rankings are comparable among different pressures, which is a simplification of how different pressures are expected to affect coral reef health (see Supporting Information for a more detailed 


\section{BOX 1}

Report cards ranking the top threats within each "50 Reef" refugium are available at https://github. com/WCS-Marine/local-reef-pressures/tree/main/BCU\%20report\%20cards. Each report card provides detailed maps of the six different pressures showing the variability of pressure within potential climate refugia, and the need to incorporate local, traditional, and regional knowledge into prioritizing management actions and locations. Variability in pressures within each " 50 Reef" is also shown in a beeswarm plot (see Figure shows the "Central Tanzania" 50 Reef as an example): each dot shows the value for one reef cell within the identified refuge, and together they show the variability of the values. The colour of the dots is proportional to the pressure percentile. In case of high variability (as for tourism in this example), the median could be zero while a few reef cells can have higher percentiles that might indicate management priorities in more localized areas. Note that reef cells with zero values are all tied to a zero percentile (blue dots).

Pressures ranked from highest to lowest; refugium's average and pixels compared to all reef pixels

A value in the $50^{\text {th }}$ percentile means that the refugium's average is higher than $50 \%$ of the world's coral reefs values

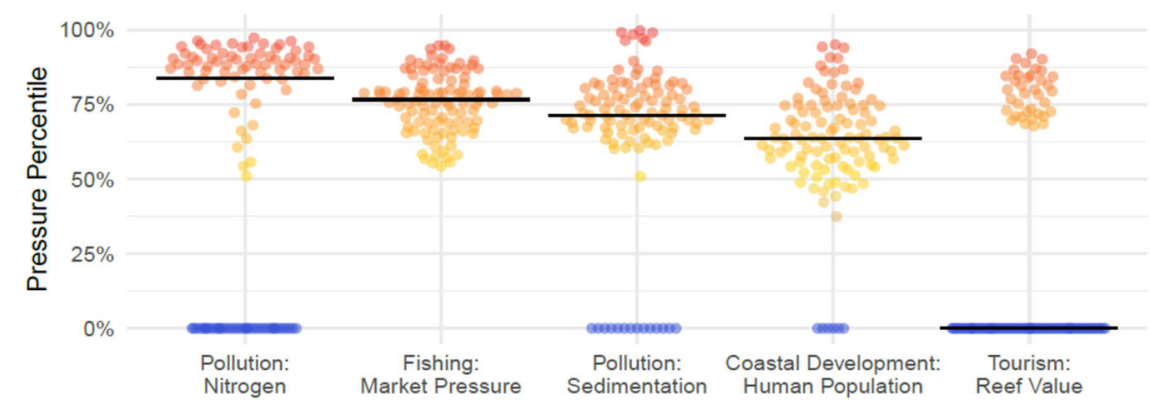

description of this limitation). Further research into globally relevant thresholds for each pressure could further refine these objective rankings into sustainable or unsustainable levels of human impacts to guide management priorities. Third, our analysis focuses on potential pressures to coral reefs and does not account for ongoing management interventions that are actively managing pressures, such as watershed management or marine protected areas. Strengthening the capacity and resources for management is obviously crucial to ensure pressures do not jeopardize coral reef persistence or ecosystem services and can sustain positive outcomes for biodiversity and coastal communities (Gill et al., 2017). And finally, we do not account for potential interactions among different pressures, which may increase or decrease their realized impacts (Côté et al., 2016). For example, protection from destructive fishing activities can reduce levels of coral disease, but this benefit is compromised in poor water quality (Lamb et al., 2016).

With the planet's oceans facing committed warming for decades and predicted to cross a series of critical climate tipping points (Heinze et al., 2021), ensuring human impacts are effectively managed is urgently required to meet climate adaptation targets of the United Nations Framework Convention on Climate Change and goals of the Post-2020 Biodiversity Framework of the Convention on Biological Diversity. With local pressures expected to expand and intensify over time (O'Hara et al., 2021) and to continue to interact dynamically with increasing climate change (He \& Silliman, 2019), tracking and mitigating the impacts of local pressures also requires access to global data layers to inform rigorous and comprehensive management planning. Here, we provide the underlying datasets and code (https://github.com/WCS-Marine/ local-reef-pressures) and examples of two use cases: report cards and an interactive global mapping platform (see Box 1 and Data Accessibility Statement). Our reproducible workflow also allows for these analyses to be easily updated with new or revised global data layers, and allows for analyses at more regional or local scales by subsetting the data used in analyses. Ensuring the future sustainability of coral reefs requires managing the impacts of climate change and human pressures using diverse portfolios of adaptive and evolving conservation and management interventions. Here, we provide a comprehensive and highly-resolved global analysis of local pressures on coral reefs to help guide managers, decision makers, and stakeholders towards interventions that can ensure this sustainability.

\section{ACKNOWLEDGMENTS}

We thank J. Cinner, K. Longley-Wood, E. Maire, E. McLeod, and M. Spalding for contributing the gravity and 
tourism value datasets, and the other sources for freely making global data layers available for this study. We are grateful to the thoughtful and insightful comments of two anonymous reviewers. Funding was provided by Bloomberg Philanthropies' Vibrant Oceans Initiative to the Wildlife Conservation Society.

\section{CONFLICT OF INTEREST}

The authors declare no conflicts of interest

\section{AUTHOR CONTRIBUTIONS}

MA, ED, AW, and GA conceived the study. AW and FS developed data layers. MA and SG conducted the analysis. MA and ED wrote the first draft. All authors edited and approved the manuscript.

\section{DATA ACCESSIBILITY STATEMENT}

Data and code for analysis are publicly accessible at https://github.com/WCS-Marine/local-reef-pressures and can be viewed in an interactive map at https://programs. wcs.org/vibrantoceans/map. Report cards are available at https://github.com/WCS-Marine/local-reef-pressures/ tree/main/BCU\%20report\%20cards

\section{O R C I D}

Marco Andrello @ https://orcid.org/0000-0001-7590-2736 Emily S. Darling (1) https://orcid.org/0000-0002-1048-2838 Amelia Wenger (1) https://orcid.org/0000-0002-0433-6164

\section{REF E REN C ES}

Allan, J. R., Watson, J. E. M., Di Marco, M., O’bryan, C. J., Possingham, H. P., Atkinson, S. C., \& Venter, O. (2019). Hotspots of human impact on threatened terrestrial vertebrates. PLoS Biology, 17(3), e3000158. https://doi.org/10.1371/journal.pbio.3000158

Bailey, M., \& Sumaila, U.r (2015). Destructive fishing and fisheries enforcement in eastern Indonesia. Marine Ecology Progress Series, 530, 195-211. https://doi.org/10.3354/meps11352

Bennett, N. J., Cisneros-Montemayor, A. M., Blythe, J., Silver, J. J., Singh, G., Andrews, N., Calò, A., Christie, P., Di Franco, A., Finkbeiner, E. M., Gelcich, S., Guidetti, P., Harper, S., Hotte, N., Kittinger, J. N., Le Billon, P., Lister, J., López De La Lama, R., Mckinley, E., ... Sumaila, U. R. (2019). Towards a sustainable and equitable blue economy. Nature Sustainability, 2(11), 991-993. https://doi.org/10.1038/s41893-019-0404-1

Beyer, H. L., Kennedy, E. V., Beger, M., Chen, C. A., Cinner, J. E., Darling, E. S., Eakin, C. M., Gates, R. D., Heron, S. F., Knowlton, N., Obura, D. O., Palumbi, S. R., Possingham, H. P., Puotinen, M., Runting, R. K., Skirving, W. J., Spalding, M., Wilson, K. A., Wood, S., ... Hoegh-Guldberg, O. (2018). Risk-sensitive planning for conserving coral reefs under rapid climate change. Conservation Letters, 11(6), e12587. https://doi.org/10.1111/conl.12587

Borrelli, P., Robinson, D. A., Fleischer, L. R., Lugato, E., Ballabio, C., Alewell, C., Meusburger, K., Modugno, S., Schütt, B., Ferro, V., Bagarello, V., Oost, K. V., Montanarella, L., \& Panagos, P. (2017). An assessment of the global impact of 21st century land use change on soil erosion. Nature Communications, 8(1), (2013). https://doi. org/10.1038/s41467-017-02142-7

Burke, L., Bryant, D., McManus, J., \& Spalding, M. (1998). Reefs at risk. World Resources Institute. https://www.wri.org/publication/ reefs-risk

Burke, L., Reytar, K., Spalding, M., \& Perry, A. (2011). Reefs at risk revisited. World Resources Institute. https://www.wri.org/ publication/reefs-risk-revisited

Campbell, S. J., Darling, E. S., Pardede, S., Ahmadia, G., Mangubhai, S., Amkieltiela, Estradivari, \& Maire, E. (2020). Fishing restrictions and remoteness deliver conservation outcomes for Indonesia's coral reef fisheries. Conservation Letters, 13(2), e12698. https://doi.org/10.1111/conl.12698

Center for International Earth Science Information Network CIESIN - Columbia University. (2018). Gridded population of the world, Version 4 (GPWv4): Population count adjusted to match 2015 revision of UN WPP country totals, revision 11. NASA Socioeconomic Data and Applications Center (SEDAC). https://doi.org/10. 7927/H4PN93PB

Cinner, J. E., Graham, N. A. J., Huchery, C., \& Macneil, M. A. (2013). Global effects of local human population density and distance to markets on the condition of coral reef fisheries. Conservation Biology, 27, 453-458.

Cinner, J. E., Huchery, C., Macneil, M. A., Graham, N. A. J., Mcclanahan, T. R., Maina, J., Maire, E., Kittinger, J. N., Hicks, C. C., Mora, C., Allison, E. H., D’agata, S., Hoey, A., Feary, D. A., Crowder, L., Williams, I. D., Kulbicki, M., Vigliola, L., Wantiez, L., ... Mouillot, D. (2016). Bright spots among the world's coral reefs. Nature, 535(7612), 416-419. https://doi.org/10.1038/nature18607

Cinner, J. E., Maire, E., Huchery, C., Macneil, M. A., Graham, N. A. J., Mora, C., Mcclanahan, T. R., Barnes, M. L., Kittinger, J. N., Hicks, C. C., D’agata, S., Hoey, A. S., Gurney, G. G., Feary, D. A., Williams, I. D., Kulbicki, M., Vigliola, L., Wantiez, L., Edgar, G. J., ... Mouillot, D. (2018). Gravity of human impacts mediates coral reef conservation gains. Proceedings of the National Academy of Sciences, 201708001. https://doi.org/10.1073/pnas.1708001115

Claar, D. C., Starko, S., Tietjen, K. L., Epstein, H. E., Cunning, R., Cobb, K. M., Baker, A. C., Gates, R. D., \& Baum, J. K. (2020). Dynamic symbioses reveal pathways to coral survival through prolonged heatwaves. Nature Communications, 11(1), 6097. https://doi.org/10.1038/s41467-020-19169-y

Côté, I. M., Darling, E. S., \& Brown, C. J. (2016). Interactions among ecosystem stressors and their importance in conservation. Proceedings of the Royal Society B: Biological Sciences, 283(1824), 20152592. https://doi.org/10.1098/rspb.2015.2592

Darling, E. S., McClanahan, T. R., Maina, J., Gurney, G. G., Graham, N. A. J., Januchowski-Hartley, F., Cinner, J. E., Mora, C., Hicks, C. C., Maire, E., Puotinen, M., Skirving, W. J., Adjeroud, M., Ahmadia, G., Arthur, R., Bauman, A. G., Beger, M., Berumen, M. L., Bigot, L., Bouwmeester, J., ... Mouillot, D. (2019). Socialenvironmental drivers inform strategic management of coral reefs in the Anthropocene. Nature Ecology \& Evolution, 3(9), 1341-1350. https://doi.org/10.1038/s41559-019-0953-8

De'ath, G., Fabricius, K. E., Sweatman, H., \& Puotinen, M. (2012). The 27-year decline of coral cover on the Great Barrier Reef and its causes. Proceedings of the National Academy of Sciences of the United States of America, 109(44), 17995-17999. https://doi.org/10. 1073/pnas.1208909109 
Eddy, T. D., Cheung, W. W. L., \& Bruno, J. F. (2018). Historical baselines of coral cover on tropical reefs as estimated by expert opinion. PeerJ, 6, e4308. https://doi.org/10.7717/peerj.4308

Gill, D. A., Mascia, M. B., Ahmadia, G. N., Glew, L., Lester, S. E., Barnes, M., Craigie, I., Darling, E. S., Free, C. M., Geldmann, J., Holst, S., Jensen, O. P., White, A. T., Basurto, X., Coad, L., Gates, R. D., Guannel, G., Mumby, P. J., Thomas, H., .. Fox, H. E. (2017). Capacity shortfalls hinder the performance of marine protected areas globally. Nature, 543(7647), 665-669. https://doi.org/10.1038/ nature 21708

Grantham, H. S., Duncan, A., Evans, T. D., Jones, K. R., Beyer, H. L., Schuster, R., Walston, J., Ray, J. C., Robinson, J. G., Callow, M., Clements, T., Costa, H. M., Degemmis, A., Elsen, P. R., Ervin, J., Franco, P., Goldman, E., Goetz, S., Hansen, A., ... Watson, J. E. M. (2020). Anthropogenic modification of forests means only $40 \%$ of remaining forests have high ecosystem integrity. Nature Communications, 11(1), 5978. https://doi.org/10.1038/s41467-02019493-3

Harris, J. L., Estradivari, E., Fox, H. E., Mccarthy, O. S., \& Ahmadia, G. N. (2017). Planning for the future: Incorporating global and local data to prioritize coral reef conservation. Aquatic Conservation: Marine and Freshwater Ecosystems, 27(S1), 65-77. https://doi.org/10.1002/aqc.2810

He, Q., \& Silliman, B. R. (2019). Climate change, human impacts, and coastal ecosystems in the anthropocene. Current Biology, 29(19), R1021-R1035. https://doi.org/10.1016/j.cub.2019.08.042

Heinze, C., Blenckner, T., Martins, H., Rusiecka, D., Döscher, R., Gehlen, M., Gruber, N., Holland, E., Hov, Ø., Joos, F., Matthews, J. B. R., Rødven, R., \& Wilson, S. (2021). The quiet crossing of ocean tipping points. Proceedings of the National Academy of Sciences, 118(9),. https://doi.org/10.1073/pnas.2008478118

Hicks, C. C., Cohen, P. J., Graham, N. A. J., Nash, K. L., Allison, E. H., D’lima, C., Mills, D. J., Roscher, M., Thilsted, S. H., ThorneLyman, A. L., \& Macneil, M. A. (2019). Harnessing global fisheries to tackle micronutrient deficiencies. Nature, 574(7776), 95-98. https://doi.org/10.1038/s41586-019-1592-6

Hoegh-Guldberg, O., Jacob, D., Taylor, M., Bindi, M., Brown, S., Camilloni, I., ..., \& Sherstyukov, B. (2018). Impacts of $1.5^{\circ} \mathrm{C}$ of Global Warming on Natural and Human Systems. In V. MassonDelmotte, P. Zhai, \& H. O. Pörtner, Global Warming of $1.5^{\circ} \mathrm{C}$. An IPCC Special Report on the impacts of global warming of $1.5^{\circ} \mathrm{C}$ above pre-industrial levels and related global greenhouse gas emission pathways, in the context of strengthening the global response to the threat of climate change, sustainable development, and efforts to eradicate poverty (p. 138). Intergovernmental Panel on Climate Change.

Lamb, J. B., True, J. D., Piromvaragorn, S., \& Willis, B. L. (2014). Scuba diving damage and intensity of tourist activities increases coral disease prevalence. Biological Conservation, 178, 88-96. https://doi.org/10.1016/j.biocon.2014.06.027

Lamb, J. B., Wenger, A. S., Devlin, M. J., Ceccarelli, D. M., Williamson, D. H., \& Willis, B. L. (2016). Reserves as tools for alleviating impacts of marine disease. Philosophical Transactions of the Royal Society B: Biological Sciences, 371(1689), 20150210. https://doi.org/10.1098/rstb.2015.0210

MacNeil, M. A., Mellin, C., Matthews, S., Wolff, N. H., McClanahan, T. R., Devlin, M., Drovandi, C., Mengersen, K., .. Graham, N. A. J. (2019). Water quality mediates resilience on the Great Barrier Reef. Nature Ecology \& Evolution, 3(4), 620-627. https://doi.org/10.1038/ s41559-019-0832-3
Maina, J., De Moel, H., Zinke, J., Madin, J., Mcclanahan, T., \& Vermaat, J. E. (2013). Human deforestation outweighs future climate change impacts of sedimentation on coral reefs. Nature Communications, 4, 1986. https://doi.org/10.1038/ncomms2986

Mcclanahan, T. R., Friedlander, A. M., Wantiez, L., Graham, N. A. J., Bruggemann, J. H., Chabanet, P., \& Oddenyo, R. M.. (2021). Bestpractice fisheries management associated with reduced stocks and changes in life histories. Fish and Fisheries. https://doi.org/10.1111/ faf.12625

Mcclanahan, T. R., Graham, N. A. J., Macneil, M. A., Muthiga, N. A., Cinner, J. E., Bruggemann, J. H., \& Wilson, S. K. (2011). Critical thresholds and tangible targets for ecosystem-based management of coral reef fisheries. Proceedings of the National Academy of Sciences, 108(41), 17230-17233. https://doi.org/10.1073/ pnas. 1106861108

Mora, C., Aburto-Oropeza, O., Ayala Bocos, A., Ayotte, P. M., Banks, S., Bauman, A. G., Beger, M., Bessudo, S., Booth, D. J., Brokovich, E., Brooks, A., Chabanet, P., Cinner, J. E., Cortés, J., Cruz-Motta, J. J., Cupul Magaña, A., Demartini, E. E., Edgar, G. J., Feary, D. A., ... Zapata, F. A. (2011). Global human footprint on the linkage between biodiversity and ecosystem functioning in reef fishes. PLoS Biology, 9, e1000606. https://doi.org/10.1371/journal. pbio.1000606

Morrison, T. H., Hughes, T. P., Adger, W. N., Brown, K., Barnett, J., \& Lemos, M. C. (2019). Save reefs to rescue all ecosystems. Nature, 573(7774), 333-336. https://doi.org/10.1038/d41586-01902737-8

O'hara, C. C., Frazier, M., \& Halpern, B. S. (2021). At-risk marine biodiversity faces extensive, expanding, and intensifying human impacts. Science, 372(6537), 84-87. https://doi.org/10.1126/science. abe6731

Oyanedel, R., Gelcich, S., \& Milner-Gulland, E. J. (2021). A framework for assessing and intervening in markets driving unsustainable wildlife use. Science of The Total Environment, 792, 148328. https://doi.org/10.1016/j.scitotenv.2021.148328

Shaver, E. C., Burkepile, D. E., \& Silliman, B. R. (2018). Local management actions can increase coral resilience to thermallyinduced bleaching. Nature Ecology \& Evolution, 2(7), 1075-1079. https://doi.org/10.1038/s41559-018-0589-0

Spalding, M., Burke, L., Wood, S. A., Ashpole, J., Hutchison, J., \& Zu Ermgassen, P. (2017). Mapping the global value and distribution of coral reef tourism. Marine Policy, 82, 104-113. https://doi.org/10. 1016/j.marpol.2017.05.014

Suchley, A., \& Alvarez-Filip, L. (2018). Local human activities limit marine protection efficacy on Caribbean coral reefs. Conservation Letters, 11(5), e12571. https://doi.org/10.1111/conl.12571

Tulloch, V. J.d, Tulloch, A. I.t, Visconti, P., Halpern, B. S., Watson, J. E.m, Evans, M. C., Auerbach, N. A., Barnes, M., Beger, M., Chadès, I., Giakoumi, S., Mcdonald-Madden, E., Murray, N. J., Ringma, J., \& Possingham, H. P. (2015). Why do we map threats? Linking threat mapping with actions to make better conservation decisions. Frontiers in Ecology and the Environment, 13(2), 91-99. https://doi.org/10.1890/140022

Tulloch, V. J. D., Turschwell, M. P., Giffin, A. L., Halpern, B. S., Connolly, R., Griffiths, L., Frazer, M., \& Brown, C. J. (2020). Linking threat maps with management to guide conservation investment. Biological Conservation, 245, 108527. https://doi.org/10.1016/ j.biocon.2020.108527

UNEP-WCMC, WorldFish Centre, WRI, \& TNC. (2010). Global distribution of warm-water coral reefs, compiled from multiple sources 
including the Millennium Coral Reef Mapping Project. Version 1.3. http://data.unep-wcmc.org/datasets/1

Wear, S. L. (2016). Missing the boat: Critical threats to coral reefs are neglected at global scale. Marine Policy, 74, 153-157. https://doi.org/10.1016/j.marpol.2016.09.009

Wear, S. L., Acuña, V., Mcdonald, R., \& Font, C. (2021). Sewage pollution, declining ecosystem health, and cross-sector collaboration. Biological Conservation, 255, 109010. https://doi.org/10.1016/ j.biocon.2021.109010

Wear, S. L., \& Thurber, R. V. (2015). Sewage pollution: mitigation is key for coral reef stewardship. Annals of the New York Academy of Sciences, 1355.

Webster, M. S., Colton, M. A., Darling, E. S., Armstrong, J., Pinsky, M. L., Knowlton, N., \& Schindler, D. E. (2017). Who should pick the winners of climate change? Trends in Ecology \& Evolution, 32(3), 167-173. https://doi.org/10.1016/j.tree.2016.12.007

Wenger, A. S., Harris, D., Weber, S., Vaghi, F., Nand, Y., Naisilisili, W., Hughes, A., Delevaux, J., Klein, C. J., Watson, J., Mumby, P. J., \& Jupiter, S. D. (2020). Best-practice forestry management delivers diminishing returns for coral reefs with increased land-clearing. Journal of Applied Ecology, 57(12), 2381-2392. https://doi.org/10. 1111/1365-2664.13743

Wenger, A. S., Harvey, E., Wilson, S., Rawson, C., Newman, S. J., Clarke, D., Saunders, B. J., Browne, N., Travers, M. J., Mcilwain,
J. L., Erftemeijer, P. L. A., Hobbs, J.-P. A., Mclean, D., Depczynski, M., \& Evans, R. D. (2017). A critical analysis of the direct effects of dredging on fish. Fish and Fisheries, 18(5), 967-985. https://doi.org/10.1111/faf.12218

Yap, W. Y., \& Lam, J. S. L. (2013). 80 million-twenty-footequivalent-unit container port? Sustainability issues in port and coastal development. Ocean \& Coastal Management, 71, $3-25$.

\section{SUPPORTING INFORMATION}

Additional supporting information may be found in the online version of the article at the publisher's website.

How to cite this article: Andrello, M., Darling, E., Wenger, A., Suárez-Castro, A. F., Gelfand, S., Ahmadia, N. A global map of human pressures on tropical coral reefs. Conservation Letters.

2022;15:e12858. https://doi.org/10.1111/conl.12858 